\title{
Degradation kinetics of anthracene by ozone on mineral oxides
}

\author{
Jinzhu Ma, Yongchun Liu, Hong $\mathrm{He}^{*}$ \\ State Key Laboratory of Environmental Chemistry and Ecotoxicology, Research Center for Eco-Environmental Sciences, Chinese Academy of Sciences, Beijing 100085, China
}

\section{A R T I C L E I N F O}

\section{Article history:}

Received 19 March 2010

Received in revised form

12 July 2010

Accepted 21 July 2010

\section{Keywords:}

Anthracene

Mineral oxides

Ozone

Heterogeneous reactions

Kinetics

\begin{abstract}
A B S T R A C T
To further understand the role of substrates on the heterogeneous reactions of polycyclic aromatic hydrocarbons, the reactions of ozone with anthracene adsorbed on different mineral oxides $\left(\mathrm{SiO}_{2}, \alpha-\mathrm{Al}_{2} \mathrm{O}_{3}\right.$ and $\alpha-\mathrm{Fe}_{2} \mathrm{O}_{3}$ ) and on Teflon disc were investigated in dark at $20^{\circ} \mathrm{C}$. No reaction between ozone and anthracene on Teflon disc was observed when the ozone concentration was $\sim 1.18 \times 10^{14}$ molecules $\mathrm{cm}^{-3}$. The reactions on mineral oxides exhibited pseudo-first-order kinetics for anthracene loss, and the pseudo-first-order rate constant $\left(k_{1, \mathrm{obs}}\right)$ displayed a Langmuir-Hinshelwood dependence on the gas-phase ozone concentration. The adsorption equilibrium constants for ozone $\left(K_{\mathrm{O}}\right)$ on $\mathrm{SiO}_{2}-1, \mathrm{SiO}_{2}-2, \alpha-\mathrm{Al}_{2} \mathrm{O}_{3}$ and $\alpha-\mathrm{Fe}_{2} \mathrm{O}_{3}$ were $(0.81 \pm 0.26) \times 10^{-15} \mathrm{~cm}^{3},(2.83 \pm 1.17) \times 10^{-15} \mathrm{~cm}^{3},(2.48 \pm 0.77) \times 10^{-15} \mathrm{~cm}^{3}$ and $(1.66 \pm 0.45) \times 10^{-15} \mathrm{~cm}^{3}$, respectively; and the maximum pseudo-first-order rate constant $\left(k_{1, \max }\right)$ on these oxides were $(0.385 \pm 0.058) \mathrm{s}^{-1},(0.101 \pm 0.0138) \mathrm{s}^{-1},(0.0676 \pm 0.0086) \mathrm{s}^{-1}$ and $(0.0457 \pm 0.004) \mathrm{s}^{-1}$, respectively. Anthraquinone was identified as the main surface product of anthracene reacted with ozone. Comparison with previous research and the results obtained in this study suggest that the reactivity of anthracene with ozone and the lifetimes of anthracene adsorbed on mineral dust in the atmosphere are determined by the nature of the substrate.
\end{abstract}

(c) 2010 Elsevier Ltd. All rights reserved.

\section{Introduction}

Polycyclic aromatic hydrocarbons (PAHs), which mainly originate from the incomplete combustion of fossil fuels (petroleum, natural gas and coal) and biomass burning, have attracted much attention due to their allergenic, mutagenic, and carcinogenic properties (Finlayson-Pitts and Pitts, 1997). The global emission of atmospheric PAHs is roughly estimated to be $0.001-0.02 \mathrm{TgC}_{\mathrm{yr}}^{-1}$ and about $90 \%$ of PAHs emissions are anthropogenic (Calvert et al., 2002). Once emitted into the atmosphere, PAHs are able to partition between the gas-phase and atmospheric particulate matter. For example, semivolatile (3-4 rings) PAHs and those with lower volatility (more than 4 rings) are frequently found adsorbed on particulate matter, especially on particles lower than $5 \mu \mathrm{m}$ in size (Pierce and Katz, 1975).

Due to interactions with atmospheric radicals and oxidants, such as $\mathrm{OH}, \mathrm{O}_{3}, \mathrm{H}_{2} \mathrm{O}_{2}, \mathrm{HNO}_{3}$, and $\mathrm{NOx}$, PAHs may undergo homogeneous or heterogeneous reactions during its atmospheric residence time. Recently, modeling and laboratory studies have shown that heterogeneous reactions may be the dominant reactive loss process of atmospheric PAHs (Kwamena et al., 2007a,b; Perraudin et al., 2007a; Miet et al., 2009). Heterogeneous reactions not only

\footnotetext{
* Corresponding author. Tel.: +86 10 62849123; fax: +86 1062923563.

E-mail address: honghe@rcees.ac.cn (H. He).
}

control the atmospheric fate and lifetime of adsorbed PAHs but also alter the physicochemical properties of particulate matter. Additionally, the products of the reaction (nitro-PAHs, oxy-PAHs) have been shown to be more carcinogenic or mutagenic (Pitts et al., 1978; Calvert et al., 2002). Field observations have found that atmospheric $\mathrm{PAH}$ concentration measured using conventional samplers without an ozone trap can underestimate the PAH concentration by more than $67 \%$ (Goriaux et al., 2006) or $50 \%$ (Schauer et al., 2003). Therefore, heterogeneous reactions between atmospheric oxidants and adsorbed PAHs attracted considerable interest over the past several decades (Pitts et al., 1978; Wu et al., 1984; Pöschl et al., 2001; Mmereki and Donaldson, 2003; Mmereki et al., 2004; Kahan et al., 2006; Kwamena et al., 2004, 2006, 2007a,b; Gloaguen et al., 2006; Perraudin et al., 2007a,b; Miet et al., 2009; Shiraiwa et al., 2009; Bedjanian et al., 2010; Bedjanian and Nguyen, 2010).

Anthracene is often used as a model PAH and its reaction with $\mathrm{O}_{3}$ on various substrates has been widely investigated. Most previous studies on the heterogeneous reactions of PAHs have focused on carbonaceous aerosols (Pöschl et al., 2001; Kahan et al., 2006; Kwamena et al., 2004, 2007b). Anthraquinone was identified as the main product of anthracene ozonation on different substrates (Mmereki et al., 2004; Gloaguen et al., 2006; Kwamena et al., 2006; Perraudin et al., 2007b). These results suggest that the nature of the substrate greatly influences the heterogeneous reactivity of $\mathrm{O}_{3}$ with PAHs adsorbed on carbonaceous aerosols. 
On the other hand, recent field measurements have found that the concentration of PAHs (sum of 16 EPA list PAHs) ranges from 1.0 to $85.5 \mu^{g^{-1}}$ in the dustfall collected in Tianjin (Wu et al., 2005), and from 0.18 to $3.52 \mu \mathrm{g} \mathrm{g}^{-1}$ in the sandstorm depositions in Beijing (Fu et al., 2009). This indicates that mineral dust can adsorb PAHs in the real atmospheric particulate matter. Mineral dust, which mainly originates from arid and semi-arid regions with global source strength of about $1000-3000 \mathrm{Tg} \mathrm{yr}^{-1}$ (Dentener et al., 1996), is one of the most important contributors to the loading of atmospheric particulate matter. Therefore, it is very significant to investigate the chemical behavior of PAHs on mineral dust. The reaction between $\mathrm{O}_{3}$ and anthracene on silica was investigated in the literature (Alebić-Juretić et al., 1990; Perraudin et al., 2007a,b). Besides $\mathrm{SiO}_{2}$, other oxides including $\alpha-\mathrm{Al}_{2} \mathrm{O}_{3}$ and $\alpha-\mathrm{Fe}_{2} \mathrm{O}_{3}$ were also regarded as the main constituents of mineral dust (Usher et al., 2003; He et al., 2005). However, kinetic parameters were unavailable for the heterogeneous reactions of $\mathrm{PAHs}$ with $\mathrm{O}_{3}$ on $\alpha-\mathrm{Al}_{2} \mathrm{O}_{3}$ and $\alpha-\mathrm{Fe}_{2} \mathrm{O}_{3}$. In addition, to our knowledge, it is unknown that how the mineral dust affects the heterogeneous reactions of PAHs with $\mathrm{O}_{3}$.

To understand how the heterogeneous reactions of PAHs with $\mathrm{O}_{3}$ proceed, it is important to determine the surface reaction mechanism. However, it is controversial in literatures about the surface reaction mechanism of PAHs on different substrates. For example, Perraudin et al. (2007a) reported that the heterogeneous reactions of $\mathrm{O}_{3}$ with PAHs on graphite and silica accords with an Eley-Rideal gas-surface reaction mechanism, signifying a linear dependence of the apparent first-order rate constants with gas-phase $\mathrm{O}_{3}$ concentration. In contrast, a Langmuir-Hinshelwood reaction mechanism has been observed on phenylsiloxane oil (Kwamena et al., 2007b), soot (Pöschl et al., 2001), azelaic acid aerosols (Kwamena et al., 2004), octanol and decanol (Kahan et al., 2006), pyrex glass (Kwamena et al., 2006) and different coated aqueous surfaces (Mmereki et al., 2004), whereby the apparent first-order rate constants become independent of the $\mathrm{O}_{3}$ concentration when saturation of the surface occurs at high gas-phase $\mathrm{O}_{3}$ concentration.

According to the main composition of authentic mineral dust (He et al., 2005) and the upper continental crust (Usher et al., 2003), $\mathrm{SiO}_{2}, \mathrm{Al}_{2} \mathrm{O}_{3}$ and $\mathrm{Fe}_{2} \mathrm{O}_{3}$ were chosen as model oxides for atmospheric particles in Beijing. In this study, the heterogeneous reactions between $\mathrm{O}_{3}$ and anthracene adsorbed on mineral oxides including $\mathrm{SiO}_{2}, \alpha-\mathrm{Al}_{2} \mathrm{O}_{3}$ and $\alpha-\mathrm{Fe}_{2} \mathrm{O}_{3}$ were investigated. The surface reaction mechanism and the effect of mineral substrates on the reaction kinetics were studied in detail. The results will help for understanding the chemical behavior of PAHs in the atmosphere.

\section{Experimental}

\subsection{Particles and characterization}

The $\mathrm{SiO}_{2}-1$ sample was purchased from Degussa (304N). The $\mathrm{SiO}_{2}-2$ sample was prepared from $\mathrm{SiO}_{2}-1$ by calcining at $1000^{\circ} \mathrm{C}$ for 3 h. The $\alpha-\mathrm{Fe}_{2} \mathrm{O}_{3}$ sample was supplied by Beijing Nanshangle Chemicals Factory. The $\alpha-\mathrm{Al}_{2} \mathrm{O}_{3}$ sample was prepared from boehmite $(\mathrm{AlOOH}$, Shandong aluminum Corporation) by calcining at $1200{ }^{\circ} \mathrm{C}$ for $3 \mathrm{~h}$. The specific surface area of these samples was measured using Nitrogen Brunauer-Emmett-Teller (BET) physisorption (Micromeritics ASAP 2000). The crystalline for these samples were identified as amorphous, hematite and corundum by a D/max-RB automatic powder X-ray diffractometer (XRD) using $\mathrm{Cu}$ $\mathrm{K} \alpha$ irradiation.

\section{2. $\mathrm{O}_{3}$ generation and detection}

$\mathrm{O}_{3}$ was generated by a homemade quartz $\mathrm{O}_{3}$ generator, in which a mixed flow of dry $\mathrm{O}_{2}$ and $\mathrm{N}_{2}$ was irradiated by a mercury lamp with wavelength of 185 and $254 \mathrm{~nm}$. The concentration of $\mathrm{O}_{3}$ in the feed gas was controlled by varying the ratio of $\mathrm{O}_{2}$ to $\mathrm{N}_{2}$ passing through the mercury lamp and was detected by an $\mathrm{O}_{3}$ monitor (Model 202, 2B Technology). The $\mathrm{O}_{3}$ concentrations were from 0 to $2.44 \times 10^{15}$ molecules $\mathrm{cm}^{-3}$ (0-99 ppm).

\subsection{Sample preparation and storage}

Before adsorption of PAHs, mineral oxides were cleaned three times by ultrasonication in dichloromethane (Chromatographic Grade), followed by drying at room temperature. The concentration of PAHs in the extract of cleaned particles and the pure solvent were confirmed to be lower than the detection limit of the gas chromatography-mass spectrometer (Agilent 6890/5973).

Anthracene was adsorbed on particles by the impregnation method. $(1.0 \pm 0.0001) \mathrm{g}$ of the cleaned particles was added into $(20.0 \pm 0.5) \mathrm{ml}$ of $\mathrm{n}$-hexane (Chromatographic Grade) containing $(500 \pm 10) \mu \mathrm{g}$ of anthracene. After stirred homogeneously, the solvent was slowly evaporated using a rotary evaporator at $30^{\circ} \mathrm{C}$. Finally, the particles were dried at room temperature for $4 \mathrm{~h}$. To avoid the photodegradation of the adsorbed PAHs, all particles in the amber glass flasks were stored at $-18{ }^{\circ} \mathrm{C}$ in dark.

\subsection{Reaction procedure and analytical methods}

This kinetic study was performed in the dark at $20^{\circ} \mathrm{C}$. The $(20.0 \pm 0.1) \mathrm{mg}$ of coated particles were evenly deposited on a Teflon disc (the geometric surface area is $3.39 \mathrm{~cm}^{2}$ ), which was then placed in a quartz reactor. In the case of reaction on Teflon disc, $(10 \pm 0.2) \mu \mathrm{g}$ of anthracene dissolved in $\mathrm{CH}_{2} \mathrm{Cl}_{2}$ was evenly distributed on the disc. Before $\mathrm{O}_{3}$ was introduced into the quartz reactor, $\mathrm{O}_{2} / \mathrm{O}_{3} / \mathrm{N}_{2}$ of a given concentration was flowed through another blank reactor. When the concentration of $\mathrm{O}_{3}$ was stable, the feed gas was switched to the reactor containing adsorbed PAHs for reaction.

The reacted particle samples were ultrasonically extracted using (20.0 \pm 0.5$) \mathrm{mL} \mathrm{CH}_{2} \mathrm{Cl}_{2}$ and were then filtered using a glass fibre filter, which had been previously cleaned in the same manner as the pure mineral oxides. Subsequently, $\mathrm{CH}_{2} \mathrm{Cl}_{2}$ was evaporated and changed to $(1.00 \pm 0.01) \mathrm{mL}$-hexane under a gentle stream of nitrogen gas at $20^{\circ} \mathrm{C}$.

Analyses of PAHs samples were performed by a GC-MS. The column was an HP 5MS ( $30 \mathrm{~m}, 0.25 \mathrm{~mm}$ i.d., $0.25 \mu \mathrm{m}$ film thickness). The methodology for the analysis of PAHs is similar to the study carried out by Perraudin et al. (2007b). $1.0 \mu \mathrm{L}$ of each sample was introduced via EPC splitless mode injection. The injector temperature was $280{ }^{\circ} \mathrm{C}$. The oven temperature was held at $90{ }^{\circ} \mathrm{C}$ for $2 \mathrm{~min}$, then increased from $90{ }^{\circ} \mathrm{C}$ to $330{ }^{\circ} \mathrm{C}$ at a rate of $10{ }^{\circ} \mathrm{C}$ min $^{-1}$ and held at $330{ }^{\circ} \mathrm{C}$ for $5 \mathrm{~min}$. Helium was used as carrier gas at a constant flow of $1.5 \mathrm{ml} \mathrm{min}^{-1}$. The interface temperature was kept at $280{ }^{\circ} \mathrm{C}$ during analysis. For identification of the product, mass detection was performed in the scan mode (mass/charge ratio ranging from 50 to 500 a.u), while for quantification of the reactant, mass detection was performed in selected ion monitoring (SIM) mode (dwell time $=10 \mathrm{~ms}$, number of cycles per second $=12.3$ ). The $m / z$ ratio of 178 was used for quantification ion and the $m / z$ ratio of 177 and 176 were used for confirmation ion for anthracene, respectively. The concentration of PAHs in solution were measured based on an external standard and the use of a calibration curve. The recovery obtained from spike and recovery experiments for anthracene on $\mathrm{SiO}_{2}-1, \mathrm{SiO}_{2}-2, \alpha-\mathrm{Al}_{2} \mathrm{O}_{3}$ and $\alpha-\mathrm{Fe}_{2} \mathrm{O}_{3}$ was $(84.5 \pm 9.31) \%,(95.6 \pm 3.51) \%,(104 \pm 4.31) \%$, and $(106 \pm 7.98) \%$, respectively. Therefore, GCMS areas were corrected for $100 \%$ recovery before quantification with the calibration curve. 


\subsection{Chemicals}

All chemicals were chromatographic grade and used without further purification. $\mathrm{CH}_{2} \mathrm{Cl}_{2}$ and $\mathrm{n}$-hexane were obtained from Baker Analyzed and Dima Technology Inc. Anthracene (99\%) and anthraquinone (99.5\%) were purchased from Acros Organics and Dr. Ehrenstorfer GmbH. Polynuclear aromatic hydrocarbon mix (the purity of anthracene is $100 \%$ and the prepared and certified analyte concentration of anthracene is 100 and $100.3 \mu \mathrm{g} \mathrm{ml}^{-1}$, respectively), which was used as the standard for calibrations, was purchased from AccuStandard, Inc. High purity $\mathrm{N}_{2}$ and $\mathrm{O}_{2}$ were supplied by Beijing AP BEIFEN Gases Inc.

\section{Results and discussion}

\subsection{Characteristics of mineral oxides and surface coverage (\%) of anthracene}

Table 1 shows the specific surface area of various substrates and the surface coverage (\%) of anthracene used in experiments. PAH surface coverage was calculated by assuming that no aggregates were formed during the coating and that PAH molecules were deposited horizontally beside each other (Perraudin et al., 2007a). The cross section of anthracene molecule was assumed to be $1 \mathrm{~nm}^{2}$ in calculations (Karcher and Fordham, 1987; Kwamena et al., 2006). Previous studies have shown that the reaction rate is faster when the surface coverage is below one monolayer of PAHs rather than above (Pöschl et al., 2001; Wu et al., 1984, 2005). However, there is no effect of PAHs fractional surface coverage on the kinetics in the submonolayer regime (Pöschl et al., 2001; Kwamena et al., 2004). Therefore, in order to eliminate the effect of anthracene coverage on reactivity, as shown in Table 1 , the surface coverage of anthracene on all oxides was kept in the submonolayer regime.

\subsection{Degradation kinetics of $\mathrm{O}_{3}$ and anthracene adsorbed on various substrates}

In order to clarify that no compound vaporization was occurring during the reaction time, prior to the study of $\mathrm{O}_{3}$ react with anthracene, the blank experiments were performed under the same conditions as those used for the oxidation reactions but without $\mathrm{O}_{3}$. The results show that vaporization of anthracene was negligible under our experimental conditions (see Fig. 1). The kinetics data on various substrates were determined by monitoring the loss of anthracene concentration as a function of $\mathrm{O}_{3}$ exposure time with $\mathrm{O}_{3}$ concentration of $(1.18 \pm 0.02) \times 10^{14}$ molecules $\mathrm{cm}^{-3}$ at $20{ }^{\circ} \mathrm{C}$ (Fig. 2). The results show that anthracene concentration measured after reactions with $\mathrm{O}_{3}$ on Teflon disc for $900 \mathrm{~s}$ was not significantly different from the initial concentration. Within our experimental precision, the smallest rate constant that can be measured is $5.7 \times 10^{-5} \mathrm{~s}^{-1}$. This value represents an upper limit of the $k_{1 \text {,obs }}$ for the reaction between $\mathrm{O}_{3}$ and anthracene on Teflon disc.

Table 1

Characteristics of mineral oxides and surface coverage of anthracene.

\begin{tabular}{lllc}
\hline Samples & $\begin{array}{l}\text { Specific surface } \\
\text { area }\left(\mathrm{m}^{2} \mathrm{~g}^{-1}\right)\end{array}$ & $\begin{array}{l}\text { ANT concentration } \\
\left(\mu \mathrm{g} \mathrm{g}^{-1}\right)\end{array}$ & $\begin{array}{l}\text { ANT surface } \\
\text { coverage (\%) }\end{array}$ \\
\hline $\mathrm{SiO}_{2}-1$ & 420.7 & 500 & 0.4 \\
$\mathrm{SiO}_{2}-2$ & 14.6 & 500 & 11.6 \\
$\alpha-\mathrm{Al}_{2} \mathrm{O}_{3}$ & 12.65 & 500 & 13.3 \\
$\alpha-\mathrm{Fe}_{2} \mathrm{O}_{3}$ & 2.74 & 500 & 61.6 \\
Teflon disc & $3.39 \mathrm{~cm}^{2 \mathrm{a}}$ & $10 \mu \mathrm{g}^{\mathrm{b}}$ & 99.6 \\
\hline
\end{tabular}

a The geometric surface area of the Teflon disc.

b $10 \mu \mathrm{g}$ per Teflon disc.

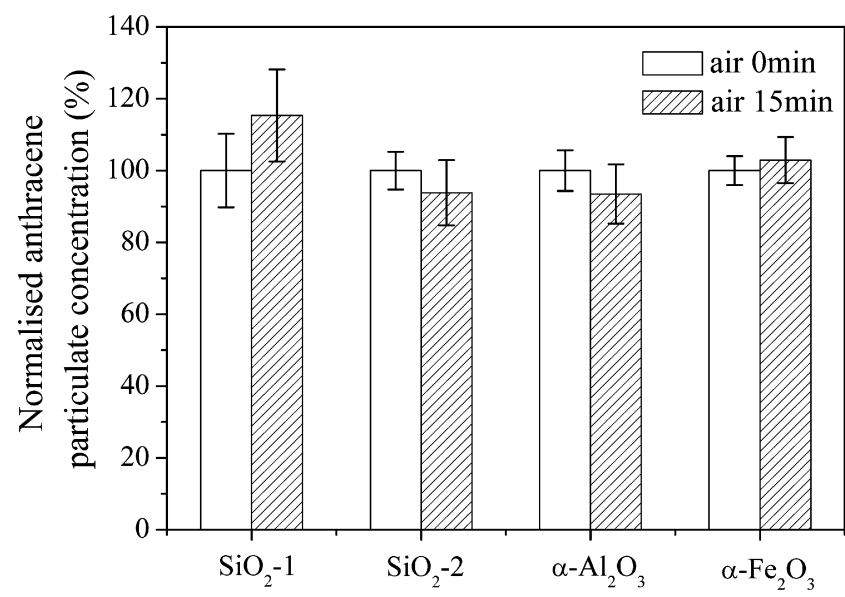

Fig. 1. Vaporization study for the anthracene adsorbed on $\mathrm{SiO}_{2}-1, \mathrm{SiO}_{2}-2, \alpha-\mathrm{Al}_{2} \mathrm{O}_{3}$ and $\alpha-\mathrm{Fe}_{2} \mathrm{O}_{3}$ particles in air flow ( $n=3$, error bars represent 1 standard deviation of the triplicate analysis performed every time).

However, degradation of anthracene was very prominent on $\mathrm{SiO}_{2}$, $\alpha-\mathrm{Al}_{2} \mathrm{O}_{3}$ and $\alpha-\mathrm{Fe}_{2} \mathrm{O}_{3}$, which all exhibited an exponential behavior. They suggest that the reactions are reasonably described by pseudo-first-order kinetics. Therefore, the experimental data were fitted using pseudo-first-order exponential functions, as shown in equation (1) (Perraudin et al., 2007a)

$\frac{[\mathrm{PAH}]_{t}}{[\mathrm{PAH}]_{0}}=\frac{[\mathrm{PAH}]_{\text {plateau }}}{[\mathrm{PAH}]_{0}}+\frac{[\mathrm{PAH}]_{0}-[\mathrm{PAH}]_{\text {plateau }}}{[\mathrm{PAH}]_{0}} \times \exp \left(-k_{1, \mathrm{obs}} \times t\right)$

where $[\mathrm{PAH}]_{t}$ is the concentration of adsorbed $\mathrm{PAH}$ at a given time, $[\mathrm{PAH}]_{0}$ is the initial concentration of adsorbed $\mathrm{PAH},[\mathrm{PAH}]_{\text {plateau }}$ is the concentration of adsorbed PAH at the plateau (Fig. 2), and $k_{1, \mathrm{obs}}$ is the apparent rate constant of the pseudo-first-order reaction.

The $k_{1, \mathrm{obs}}$ were calculated to be $(1.67 \pm 0.22) \times 10^{-2}$, $(1.66 \pm 0.34) \times 10^{-2},(1.16 \pm 0.42) \times 10^{-2}$ and $(0.86 \pm 0.31) \times 10^{-2} \mathrm{~s}^{-1}$ on $\mathrm{SiO}_{2}-1, \mathrm{SiO}_{2}-2, \alpha-\mathrm{Al}_{2} \mathrm{O}_{3}$ and $\alpha-\mathrm{Fe}_{2} \mathrm{O}_{3}$, respectively. Perraudin et al. (2007a) studied the reactions of $\mathrm{O}_{3}$ with anthracene on various silicas. Under similar concentration of $\mathrm{O}_{3}$ and initial surface coverage of anthracene, they measured the rate constants to be from $0.9 \times 10^{-2}$ to $1.8 \times 10^{-2} \mathrm{~s}^{-1}$. The rate constants on silica measured in this study

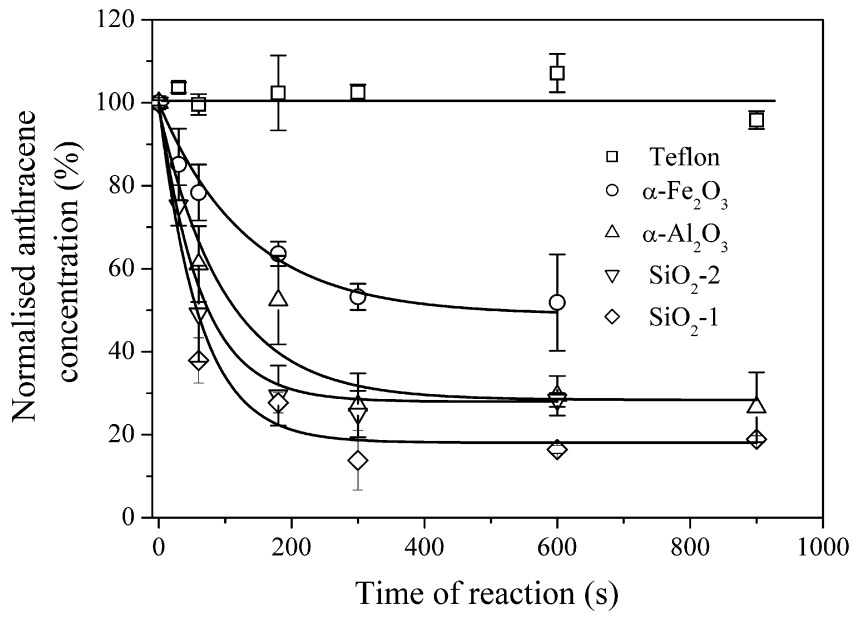

Fig. 2. Representative anthracene decays observed on various substrates with an $\mathrm{O}_{3}$ concentration of $(1.18 \pm 0.02) \times 10^{14}$ molecules $\mathrm{cm}^{-3}$ at $20{ }^{\circ} \mathrm{C}(n=3$, error bars represent 1 standard deviation of the triplicate analysis performed every time). 
are in good agreement with their results within experimental uncertainties. The fraction of unreacted anthracene was about $20 \%$, $30 \%, 30 \%$ and $55 \%$ on $\mathrm{SiO}_{2}-1, \mathrm{SiO}_{2}-2, \alpha-\mathrm{Al}_{2} \mathrm{O}_{3}$ and $\alpha-\mathrm{Fe}_{2} \mathrm{O}_{3}$, respectively. The plateau shown in Fig. 2 was related to the specific surface area of the particle sample. $\mathrm{SiO}_{2}-1$ with the largest specific surface area has the lowest plateau. Perraudin et al. (2007a) also reported that the degradation of PAHs reached a plateau on silica and the plateau was dependent on the specific surface area of particle samples. Kwamena et al. (2006) observed unreacted anthracene at both high and low anthracene surface coverage, which suggested that the anthracene was not being deposited as a smooth, uniform layer, but more likely as clumps or islands under their conditions even in a submonolayer regime. Therefore, similar to the phenomenon reported by Perraudin et al. (2007a) and Kwamena et al. (2006), the plateau observed in this study was corresponded to a complex gas-solid reaction, which depended upon both the extent of PAH multilayering and the extent to which oxidized species hindered the oxidation of the subsurface material. The apparent rate constants of the reaction of $\mathrm{O}_{3}$ reacted with anthracene adsorbed on $\mathrm{SiO}_{2}-1$ and $\mathrm{SiO}_{2}-2$ were the same within the experimental precision of the current method, illustrating that the surface coverage under one monolayer has no influence on the reaction between $\mathrm{O}_{3}$ and anthracene when the concentration of $\mathrm{O}_{3}$ was $(1.18 \pm 0.02) \times 10^{14}$ molecules $\mathrm{cm}^{-3}$. As mentioned above, Kwamena et al. (2004) also found that the rate constants were not affected by the surface coverage in the submonolayer regime. The $\mathrm{SiO}_{2}-2$ and $\alpha$ $\mathrm{Al}_{2} \mathrm{O}_{3}$ have similar specific surface areas, but the reaction on $\mathrm{SiO}_{2}-2$ was faster than that on $\alpha-\mathrm{Al}_{2} \mathrm{O}_{3}$. Thus, the difference of $k_{1, \mathrm{obs}}$ on $\mathrm{SiO}_{2}$, $\alpha-\mathrm{Al}_{2} \mathrm{O}_{3}$ and $\alpha-\mathrm{Fe}_{2} \mathrm{O}_{3}$ was due to the effect of the nature of substrate.

\subsection{Degradation mechanism of $\mathrm{O}_{3}$ and anthracene adsorbed on various substrates}

In order to clarify the surface reaction mechanism of $\mathrm{O}_{3}$ with anthracene adsorbed on these substrates, the $k_{1 \text { obs }}$ at different gasphase $\mathrm{O}_{3}$ concentrations were measured. As shown in Fig. 3, the plot of $k_{1 \text {,obs }}$ is nonlinearly related to gas-phase $\mathrm{O}_{3}$ concentration, which is consistent with the Langmuir-Hinshelwood reaction mechanism. This mechanism involves two species in which one reactant (i.e. the PAHs) is adsorbed on the particle surface while a second reactant (i.e. $\mathrm{O}_{3}$ ) is in equilibrium between the gas phase and the surface. The surface reaction takes place between two adsorbed species on the surface of the substrates. This kind of mechanism was observed for the reaction between surface-bound PAHs and $\mathrm{O}_{3}$ on different substrates (Pöschl et al., 2001; Kahan et al., 2006; Kwamena et al., 2004, 2006, 2007b; Mmereki et al., 2004).

The principles of the Langmuir-Hinshelwood model are similar to the Langmuir adsorption isotherm, assuming that the adsorption of the gas-phase species cannot proceed beyond monolayer coverage. Therefore, there are a limited number of sites for $\mathrm{O}_{3}$ adsorption. When the surface is saturated at high gas-phase $\mathrm{O}_{3}$ concentration, the rate of the reaction should become independent of the $\mathrm{O}_{3}$ concentration.

In the Langmuir-Hinshelwood mechanism, the $k_{1, \mathrm{obs}}$ can be interpreted as (Pöschl et al., 2001, 2007; Mmereki and Donaldson, 2003; Mmereki et al., 2004; Kahan et al., 2006; Kwamena et al., 2004, 2006, 2007b)

$k_{1, \mathrm{obs}}=\frac{k_{2}[\mathrm{SS}]_{s} K_{\mathrm{O}_{3}}\left[\mathrm{O}_{3}\right]_{g}}{1+K_{\mathrm{O}_{3}}\left[\mathrm{O}_{3}\right]_{g}}$

where $[\mathrm{SS}]_{s}$ is the surface concentration of ozone adsorption sites, $K_{\mathrm{O} 3}$ is the Langmuir adsorption equilibrium constant for $\mathrm{O}_{3}$, i.e. the ratio of rate constants between the adsorption and desorption of $\mathrm{O}_{3}$ $\left(k_{\mathrm{a}, \mathrm{O} 3} / k_{\mathrm{d}, \mathrm{O} 3}\right),\left[\mathrm{O}_{3}\right]_{\mathrm{g}}$ is the gas-phase concentration of $\mathrm{O}_{3}$. From this equation, it is evident that $k_{1 \text {,obs }}$ is dependent on both the number of surface sites and the gas-phase species concentration of $\mathrm{O}_{3}$. The $k_{2}[\mathrm{SS}]_{s}$ represents the maximum pseudo-first-order rate constant of anthracene at high $\mathrm{O}_{3}$ concentration $\left(\theta_{\mathrm{O}_{3}} \rightarrow 1\right)$, and is replaced with $k_{1, \text { max }}$. Then equation (2) can be modified as (Kwamena et al., 2004, 2006, 2007b)

$k_{1, \mathrm{obs}}=\frac{k_{1, \text { max }} K_{\mathrm{O}_{3}}\left[\mathrm{O}_{3}\right]_{g}}{1+K_{\mathrm{O}_{3}}\left[\mathrm{O}_{3}\right]_{g}}$

Fig. 3 shows the fitting curves based on equation (3) using nonlinear least-squares fitting. The fitting parameters, including $K_{\mathrm{O}_{3}}$ and $k_{1 \text {,max }}$ are listed in Table 2 . The errors for these parameters were obtained from the statistical errors of the nonlinear leastsquares fitting.

As can be seen in Fig. 3, the reactions between $\mathrm{O}_{3}$ and anthracene adsorbed on $\mathrm{SiO}_{2}-1, \mathrm{SiO}_{2}-2, \alpha-\mathrm{Al}_{2} \mathrm{O}_{3}$, and $\alpha-\mathrm{Fe}_{2} \mathrm{O}_{3}$ are in accordance with the Langmuir-Hinshelwood mechanism. The correlation coefficients were $0.989,0.985,0.984$, and 0.994 , respectively. Although most previous studies have provided evidence that the Langmuir-Hinshelwood is a general mechanism in the reaction of $\mathrm{O}_{3}$ and surface-adsorbed anthracene (Mmereki and Donaldson, 2003; Mmereki et al., 2004; Kahan et al., 2006; Kwamena et al., 2006, 2007b), an Eley-Rideal reaction mechanism was observed for the reaction between $\mathrm{O}_{3}$ and $\mathrm{PAHs}$ on $\mathrm{SiO}_{2}$ in the studies by Perraudin et al. (2007a), Miet et al. (2009), Alebić-Juretić et al. (1990) and Wu et al. (1984). However, the ozone concentrations in previous studies fall within the linear regime of this study. A Langmuir-Hinshelwood reaction mechanism should have been observed if these studies had been carried out over a larger $\mathrm{O}_{3}$ concentration range.

The fitting parameters $\left(K_{\mathrm{O}_{3}}\right.$ and $\left.k_{1 \text {,max }}\right)$ for the reactions between $\mathrm{O}_{3}$ and anthracene adsorbed on various substrates are summarized along with literature results in Table 2 . The $K_{\mathrm{O}_{3}}$ values range from $0.81 \times 10^{-15} \mathrm{~cm}^{3}$ to $2.83 \times 10^{-15} \mathrm{~cm}^{3}$ on $\mathrm{SiO}_{2}-1, \mathrm{SiO}_{2}-2, \alpha-\mathrm{Al}_{2} \mathrm{O}_{3}$, and $\alpha-\mathrm{Fe}_{2} \mathrm{O}_{3}$ in this study and range from $0.49 \times 10^{-15} \mathrm{~cm}^{3}$ to $2.8 \times 10^{-15} \mathrm{~cm}^{3}$ in the literature work except the reaction on phenylsiloxane oil. Kwamena et al. (2007b) compared the $K_{\mathrm{O}_{3}}$ values on different substrates and proposed that $\mathrm{O}_{3}$ prefers partitioning to nonpolar surfaces. Phenylsiloxane oil is nonpolar which contains many phenyl and methyl groups. Therefore, it has a much higher $K_{\mathrm{O}_{3}}$ values. As shown in Table 2, the small value of $K_{\mathrm{O}_{3}}$ on the surface of water suggests the strong polarity of water, and the middle values of $K_{\mathrm{O}_{3}}$ on $\mathrm{SiO}_{2}-1, \mathrm{SiO}_{2}-2, \alpha-\mathrm{Al}_{2} \mathrm{O}_{3}$, and $\alpha-\mathrm{Fe}_{2} \mathrm{O}_{3}$ suggest the moderate polarity of these oxides.

The decomposition mechanism of $\mathrm{O}_{3}$ on metal oxides is shown as follows (Li et al., 1998; Li and Oyama, 1998; Oyama, 2000):

$\mathrm{O}_{3}+* \rightarrow \mathrm{O}^{*}+\mathrm{O}_{2}$

$\mathrm{O}_{3}+\mathrm{O}^{*} \rightarrow \mathrm{O}_{2}^{*}+\mathrm{O}_{2}$

$\mathrm{O}_{2}^{*} \rightarrow *+\mathrm{O}_{2}$

where the asterisk represents surface sites and $\mathrm{O}_{2}{ }^{*}$ is the peroxide species. It means $\mathrm{O}_{3}$ can catalytically decompose into surface $\mathrm{O}$ atom and molecular $\mathrm{O}_{2}$. However, as proposed by Kwamena et al. (2006), Mmereki et al. (2004) and Perraudin et al. (2007b), ozonization of surface-bound anthracene involves the addition reaction between molecular ozone and the 9- and 10-C positions of anthracene via an ozonide intermediate. This was well supported by that 9,10-anthraquinone was found as the major product on the mineral oxides (Fig. 5). Therefore, the decomposition of $\mathrm{O}_{3}$ by metal oxide should slow down the rate of anthracene degradation on the mineral oxide by decreasing the surface concentration of molecular ozone. Thus, it can be speculated that the metal oxide with higher catalytic activity for $\mathrm{O}_{3}$ decomposition should show lower degradation rate of anthracene by $\mathrm{O}_{3}$. 

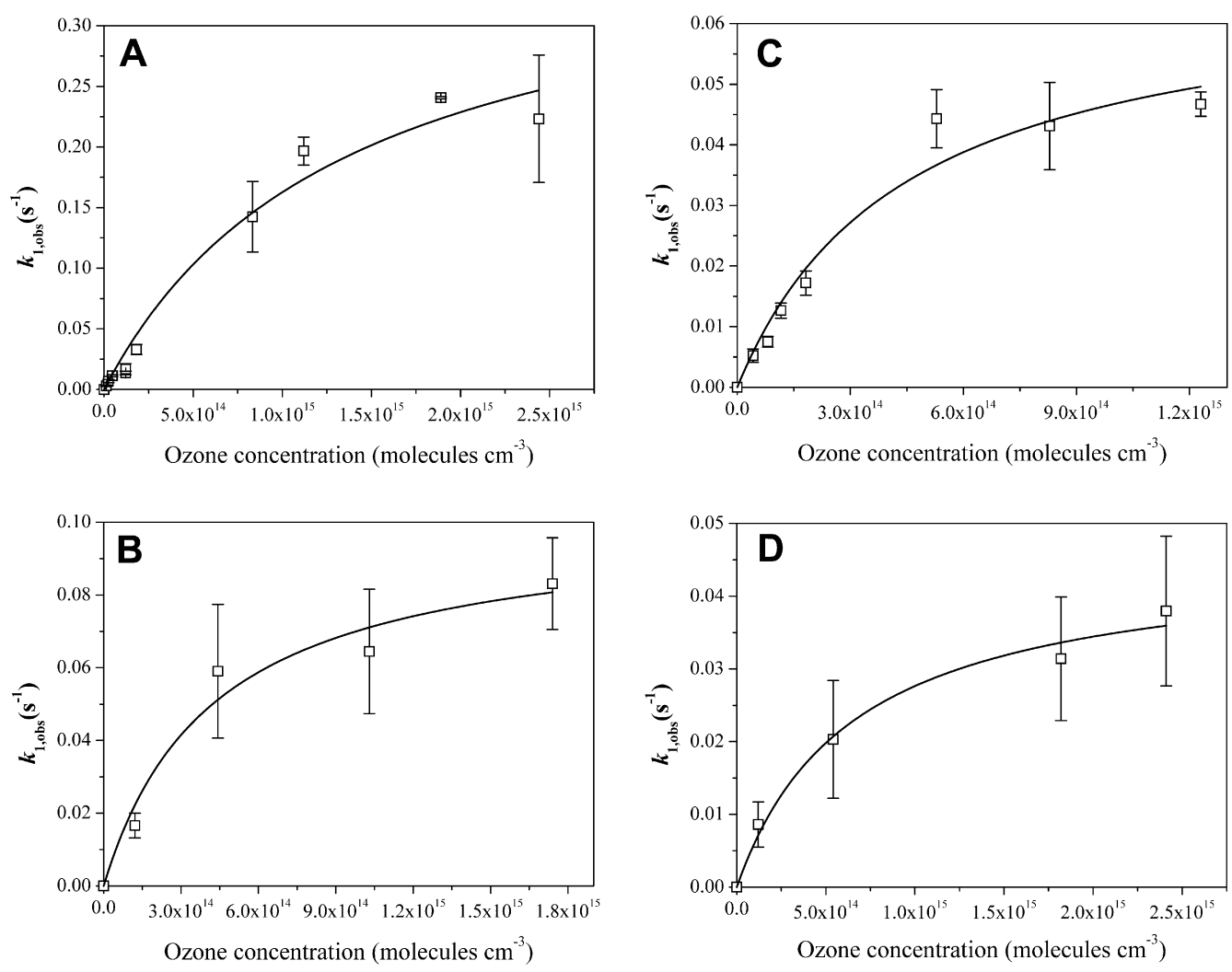

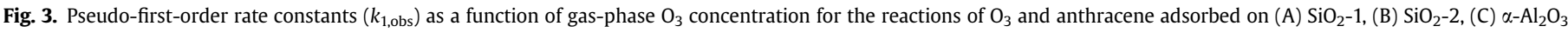
and (D) $\alpha-\mathrm{Fe}_{2} \mathrm{O}_{3}$. The error bars represent the standard error of the corresponding anthracene decay plots ( \pm 1 s.e.).

In order to further explain the effect of $\mathrm{O}_{3}$ decomposition on these reactions, the magnitude of the decomposition rate of $\mathrm{O}_{3}$ on mineral oxides $\left(K_{\mathrm{h}, \mathrm{O}_{3}}\right)$ was estimated. Because we cannot directly measure the $k$ or $\gamma$ of ozone on these oxides, $K_{\mathrm{h}, \mathrm{O}_{3}}$ was estimated based on the mass-independent steady-state reactive uptake coefficient of $\mathrm{O}_{3}$ on these three mineral oxides $\left(0\right.$ on $\mathrm{SiO}_{2}, 7.6 \times 10^{-6}$ on $\alpha-\mathrm{Al}_{2} \mathrm{O}_{3}$ and $2.2 \times 10^{-5}$ on $\alpha-\mathrm{Fe}_{2} \mathrm{O}_{3}$, respectively) reported by Michel et al. (2003) and the specific surface area of these mineral oxides in this study. The value of $K_{\mathrm{h}, \mathrm{O}_{3}}$ were calculated according to (Ravishankara, 1997)
$k=\frac{\varpi_{\mathrm{O}_{3}} A \gamma}{4}$

where $A$ is the surface area for reactions in square centimeters per cubic centimeter of air, $\varpi$ is the mean molecular speed of ozone molecules give by $\left[8 \mathrm{RT} /\left(\pi M_{\mathrm{O}_{3}}\right)\right]^{1 / 2}$, where $\mathrm{R}$ stands for the gas constant, $\mathrm{T}$ is the absolute temperature and $\mathrm{M}_{\mathrm{O}_{3}}$ is the molar mass of ozone $\left(\varpi_{\mathrm{O}_{3}}=3.62 \times 10^{4} \mathrm{~cm} \mathrm{~s}^{-1}\right.$ at $\left.298 \mathrm{~K}\right)$ and $\gamma$ is the uptake coefficient of ozone on mineral oxides. The value of $A$ was calculated according to

Table 2

Comparison of kinetic parameters and lifetimes for the reaction of ozone with anthracene adsorbed on various substrates.

\begin{tabular}{|c|c|c|c|c|c|c|}
\hline Substrates & $k_{1, \max }\left(10^{-2} \mathrm{~s}^{-1}\right)$ & $K_{\mathrm{O}_{3}}\left(10^{-15} \mathrm{~cm}^{3}\right)$ & $\begin{array}{l}\text { Reaction } \\
\text { mechanism }^{\mathrm{b}}\end{array}$ & $\begin{array}{l}\text { Clean air conditions } \\
{\left[\mathrm{O}_{3}\right]=25 \mathrm{ppb}(\mathrm{h})}\end{array}$ & $\begin{array}{l}\text { Polluted air conditions } \\
{\left[\mathrm{O}_{3}\right]=500 \mathrm{ppb}(\mathrm{min})}\end{array}$ & Refs. \\
\hline $\mathrm{SiO}_{2}$ & $\mathrm{~N} / \mathrm{A}$ & $\mathrm{N} / \mathrm{A}$ & E-R & 3.00 & 10.0 & Perraudin et al., 2007a \\
\hline graphite & $\mathrm{N} / \mathrm{A}$ & $\mathrm{N} / \mathrm{A}$ & E-R & 4.50 & 15.0 & Perraudin et al., 2007a \\
\hline phenylsiloxane oil & $1.00 \pm 0.30$ & $100 \pm 40.0$ & L-H & $4.80 \times 10^{-1}$ & 3.00 & Kwamena et al., 2007b \\
\hline azelaic acid & $5.70 \pm 0.90$ & $2.20 \pm 0.90$ & L-H & 3.61 & 11.1 & Kwamena et al., 2007b \\
\hline decanol & $0.25 \pm 0.10^{\mathrm{a}}$ & $0.58 \pm 0.13^{\mathrm{a}}$ & L-H & 309 & 934 & Kahan et al., 2006 \\
\hline pyrex tubes & $0.64 \pm 0.18$ & $2.80 \pm 0.90$ & L-H & 25.3 & 78.2 & Kwamena et al., 2006 \\
\hline water & $0.26 \pm 0.02^{\mathrm{a}}$ & $0.49 \pm 0.10^{\mathrm{a}}$ & L-H & 364 & $1.10 \times 10^{3}$ & Mmereki et al., 2004 \\
\hline stearic acid film on water & $0.23 \pm 0.02^{\mathrm{a}}$ & $0.56 \pm 0.14^{a}$ & L-H & 360 & $1.09 \times 10^{3}$ & Mmereki et al., 2004 \\
\hline 1-octanol & $0.26 \pm 0.01^{\mathrm{a}}$ & $2.03 \pm 0.35^{\mathrm{a}}$ & L-H & 86.0 & 264 & Mmereki et al., 2004 \\
\hline octanoic acid & $0.11 \pm 0.01^{\mathrm{a}}$ & $1.80 \pm 0.76^{\mathrm{a}}$ & L-H & 227 & 695 & Mmereki et al., 2004 \\
\hline hexanoic acid & $0.05 \pm 0.01^{\mathrm{a}}$ & $0.93 \pm 0.28^{\mathrm{a}}$ & $\mathrm{L}-\mathrm{H}$ & $1.01 \times 10^{3}$ & $3.06 \times 10^{3}$ & Mmereki et al., 2004 \\
\hline $\mathrm{SiO}_{2}-1$ & $38.50 \pm 5.80$ & $0.81 \pm 0.26$ & $\mathrm{~L}-\mathrm{H}$ & 1.44 & 4.40 & This work \\
\hline $\mathrm{SiO}_{2}-2$ & $10.10 \pm 1.38$ & $2.83 \pm 1.17$ & L-H & 1.58 & 4.91 & This work \\
\hline$\alpha-\mathrm{Al}_{2} \mathrm{O}_{3}$ & $6.76 \pm 0.86$ & $2.48 \pm 0.77$ & L-H & 2.70 & 8.30 & This work \\
\hline$\alpha-\mathrm{Fe}_{2} \mathrm{O}_{3}$ & $4.57 \pm 0.40$ & $1.66 \pm 0.45$ & L-H & 5.96 & 18.2 & This work \\
\hline Teflon disc & $\mathrm{N} / \mathrm{A}$ & $\mathrm{N} / \mathrm{A}$ & N/A & $>955$ & $>2.87 \times 10^{3}$ & This work \\
\hline
\end{tabular}

a : These data were converted from A and B parameters used by Kahan et al. (2006) and Mmereki et al. (2004).

b : E-R, Eley-Rideal mechanism; L-H, Langmuir-Hinshelwood mechanism. 


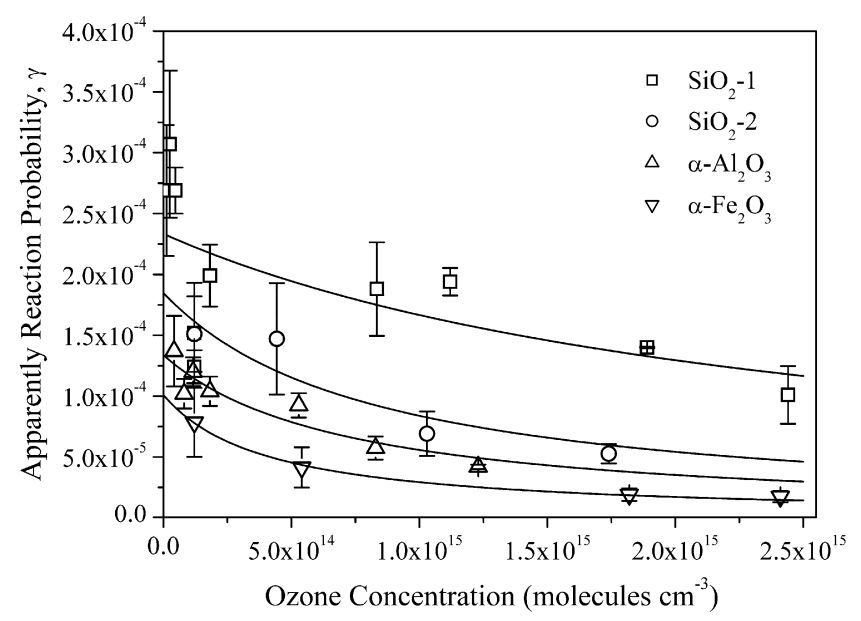

Fig. 4. Apparent reaction probability for anthracene- $\mathrm{O}_{3}$ reaction as a function of gasphase $\mathrm{O}_{3}$ concentration on $\mathrm{SiO}_{2}-1, \mathrm{SiO}_{2}-2, \alpha-\mathrm{Al}_{2} \mathrm{O}_{3}$ and $\alpha-\mathrm{Fe}_{2} \mathrm{O}_{3}$. The error bars represent the standard error of the corresponding anthracene decay plots ( \pm 1 s.e.).

$A=\frac{A_{s}}{V}$

where $A_{\mathrm{S}}$ is the surface area of the sample, $V$ is the volume of the reactor cell. Because the amount of the sample for reaction is only $20 \mathrm{mg}$, it is supposed that all the surface area of the sample is effective for the reaction during reaction time.

The value of $K_{\mathrm{h}, \mathrm{O}_{3}}$ on $\mathrm{SiO}_{2}-1, \mathrm{SiO}_{2}-2, \alpha-\mathrm{Al}_{2} \mathrm{O}_{3}$, and $\alpha-\mathrm{Fe}_{2} \mathrm{O}_{3}$ was calculated to be $0,0,2.69 \times 10^{-2}$ and $2.78 \times 10^{-2} \mathrm{~s}^{-1}$, respectively. This suggests that the decomposition activity of $\mathrm{O}_{3}$ on these oxides followed the order: $\alpha-\mathrm{Fe}_{2} \mathrm{O}_{3}>\alpha-\mathrm{Al}_{2} \mathrm{O}_{3}>\mathrm{SiO}_{2}$. It should be noted that the values of $K_{\mathrm{h}, \mathrm{O}_{3}}$ and $k_{1, \max }$ are comparable. Thus the consumption of $\mathrm{O}_{3}$ by anthracene is in competition with the decomposition of $\mathrm{O}_{3}$ on $\alpha-\mathrm{Fe}_{2} \mathrm{O}_{3}$ and $\alpha-\mathrm{Al}_{2} \mathrm{O}_{3}$. Therefore, the catalytic decomposition of $\mathrm{O}_{3}$ on different mineral oxides can affect the reaction of $\mathrm{O}_{3}$ with anthracene adsorbed on these mineral oxides. It should be pointed out that the uptake coefficient of ozone was dependent on the initial ozone concentration. The uptake coefficient were measured over a range of $10^{11}-10^{12}$ molecules $\mathrm{cm}^{-3}$ of ozone in the literature (Michel et al., 2003), however, the concentration of ozone used in this work was in a range of $10^{13}-10^{15}$ molecules $\mathrm{cm}^{-3}$. Thus, the calculated values of $K_{\mathrm{h}, \mathrm{O}_{3}}$ may

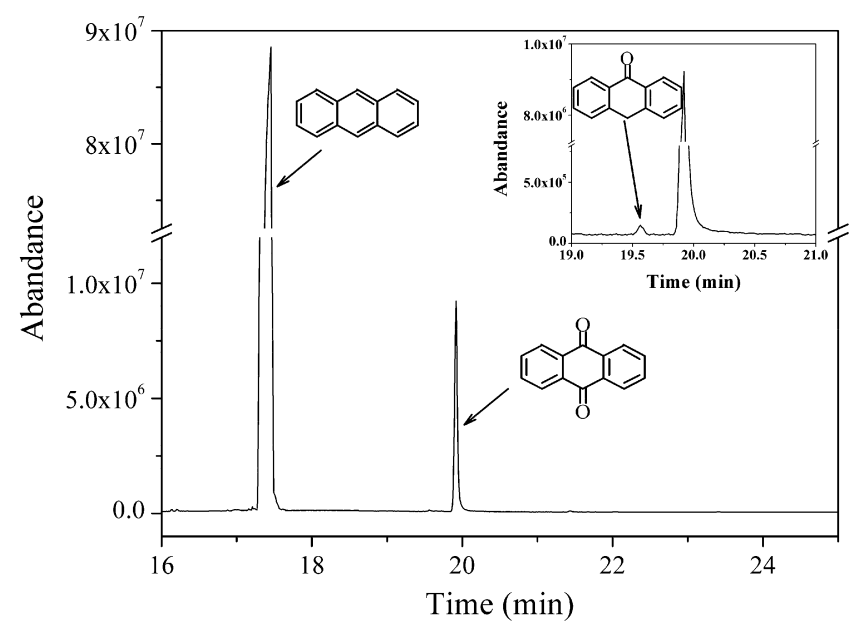

Fig. 5. Typical GC chromatogram of the extract from $\alpha-\mathrm{Al}_{2} \mathrm{O}_{3}$ on which anthracene reacted with $\mathrm{O}_{3}$. only coarsely reflect the decomposition activity of ozone on different oxides.

In fact, the value of $\mathrm{K}_{\mathrm{O}_{3}}$ indicates the availability of adsorbed $\mathrm{O}_{3}$ for the reaction. Kwamena et al. (2006) found the aerosol surface is the main factor in determining the lifetime of the surface-bound PAHs because the nature of the surface determines the availability of the adsorbed $\mathrm{O}_{3}$. However, in the case of anthracene, the similarity of $\mathrm{K}_{\mathrm{O}_{3}}$ values suggests that $\mathrm{O}_{3}$ partitions in a similar fashion on all four surfaces, which indicates that such partitioning, as described by $K_{\mathrm{O}_{3}}$, may not be the primary factor driving the heterogeneous reactions between $\mathrm{O}_{3}$ and anthracene adsorbed on mineral oxides. Therefore, other possibilities should be considered, such as the difference in $k_{1, \max }$ that represents the intrinsic catalytic activity $\left(k_{2}\right)$, and the maximum number of sites for $\mathrm{O}_{3}$ adsorption on a substrate ([SS]). As can be seen in Table 2 , the difference in $k_{1, \max }$ between $\mathrm{SiO}_{2}-1$ and $\mathrm{SiO}_{2}-2$ can be attributed to the greater number of available surface sites for ozone on $\mathrm{SiO}_{2}-1$ than on $\mathrm{SiO}_{2}-2$. $\mathrm{SiO}_{2}-2$ and $\alpha-\mathrm{Al}_{2} \mathrm{O}_{3}$ almost have the same surface area, but the $k_{1, \max }$ between them is distinct, which indicates that the intrinsic catalytic activity $\left(k_{2}\right)$ also plays an important role in the reaction between anthracene and ozone. Therefore, the reactivity of anthracene adsorbed on mineral dust with $\mathrm{O}_{3}$ is determined by the nature of the substrate through $k_{1, \max }$. On the other hand, the migrations of surface-adsorbed anthracene via desorption/adsorption may play a role in the micro-interfacial process of the heterogeneous reaction. The interaction between anthracene molecules and the substrate need to be further studied in the future works.

In order to evaluate the contribution of heterogeneous reactions of PAHs with $\mathrm{O}_{3}$ to the loss of ozone in the troposphere, the uptake coefficient $(\gamma)$ of $\mathrm{O}_{3}$ was calculated based on the pseudo-first-order rate constant, as mentioned above. The uptake coefficient is the ratio of the number of collisions that result in a reaction to the total number of collisions between a gas-phase molecule and a surface. For a simple bimolecular reaction mechanism, the uptake coefficient is calculated as follows (Ravishankara, 1997)

$\gamma=\frac{4 k_{1, \mathrm{obs}}}{\sigma_{\mathrm{ANT}} \varpi_{\mathrm{O}_{3}}\left[\mathrm{O}_{3}\right]_{g}}$

where $\sigma_{\mathrm{ANT}}$ represents the collision cross section of the anthracene molecule and $\varpi$ is the mean thermal velocity of $\mathrm{O}_{3}$. However, this equation must be modified with equation (3) when the reaction is described by the Langmuir-Hinshelwood model (Ammann et al., 2003; Pöschl et al., 2007)

$$
\gamma=\frac{4 k_{1, \max } K_{\mathrm{O}_{3}}}{\sigma_{\mathrm{ANT}} \varpi_{\mathrm{O}_{3}}\left(1+K_{\mathrm{O}_{3}}\left[\mathrm{O}_{3}\right]_{g}\right)}
$$

The uptake coefficients of $\mathrm{O}_{3}$ on anthracene at different $\mathrm{O}_{3}$ concentration are obtained based on the $k_{1, \text { obs }}$ measured in this work according to equation (7) and shown in Fig. 4 . The error of the uptake coefficients was taken as the standard error of $k_{1, \text { obs. }}$ The curve illustrates a trend of decreasing of uptake coefficient with increasing of $\mathrm{O}_{3}$ concentration, which was obtained from a nonlinear least-squares fit according to equation (7). In other studies, the reactions of $\mathrm{O}_{3}$ and PAHs adsorbed on soot, azalaic acid aerosol and the air-aqueous interface have also exhibited a similar trend between uptake coefficients and $\mathrm{O}_{3}$ concentrations (Pöschl et al., 2001; Mmereki and Donaldson, 2003; Kwamena et al., 2004). This trend is attributed to more ineffective collisions between gas-phase $\mathrm{O}_{3}$ and the particle surface at higher $\mathrm{O}_{3}$ concentrations when the $\mathrm{O}_{3}$ surface coverage was saturated (Kwamena et al., 2004). The maximum values (when $\mathrm{O}_{3}$ concentration is approaching zero) of the apparent uptake coefficient were $4.07 \times 10^{-4}$ on $\mathrm{SiO}_{2}-1,2.64 \times 10^{-4}$ on $\mathrm{SiO}_{2}-2,1.47 \times 10^{-4}$ on $\alpha-\mathrm{Al}_{2} \mathrm{O}_{3}$ 
and $1.03 \times 10^{-4}$ on $\alpha-\mathrm{Fe}_{2} \mathrm{O}_{3}$. The maximum uptake coefficient of ozone on anthracene was close to the initial reactive uptake coefficients of $\mathrm{O}_{3}$ on $\mathrm{SiO}_{2}, \alpha-\mathrm{Al}_{2} \mathrm{O}_{3}$ and $\alpha-\mathrm{Fe}_{2} \mathrm{O}_{3}$ measured by Michel et al. (2003). Because the uptake of $\mathrm{O}_{3}$ by anthracene is small and the concentration of anthracene in the atmosphere is trace, the contribution of heterogeneous reactions of $\mathrm{PAHs}$ with $\mathrm{O}_{3}$ to the loss of ozone in the troposphere can be ignored. The uptake coefficients of $\mathrm{O}_{3}$ measured in this work were higher than the values reported for $\mathrm{O}_{3}$ reaction with benzo[ $\alpha$ ]pyrene on soot (Pöschl et al., 2001) and azalaic acid (Kwamena et al., 2004). The uptake coefficients of $\mathrm{O}_{3}$ were also higher than the values for $\mathrm{O}_{3}$ reaction with anthracene at the air-aqueous interface (Mmereki and Donaldson, 2003). The results also suggest a strong effect of substrate on this reaction.

\subsection{Products of anthracene degradation}

The chromatogram of the particle extract was similar for the different mineral oxides. Fig. 5 shows a representative chromatogram of the extract from $\alpha-\mathrm{Al}_{2} \mathrm{O}_{3}$ on which anthracene reacted with $\mathrm{O}_{3}$. On the basis of their unique EI mass spectra, three peaks in the chromatogram were identified as anthracene, anthrone and anthraquinone at retention times of 17.44, 19.56 and $19.92 \mathrm{~min}$, respectively. Additionally, anthracene and anthraquinone were confirmed by the spectra of standard samples.

\subsection{The lifetime of anthracene}

The atmospheric lifetimes $(\tau)$ of anthracene were calculated based on the rate constants according to equation (8) (Pflieger et al., 2009)

$\tau=\frac{1}{k_{1, \mathrm{obs}}}$

and assuming that the heterogeneous reactions of $\mathrm{O}_{3}$ with anthracene is the only degradation process occurring in the atmosphere. The values of $k_{1, \text { obs }}$ under different concentrations of $\mathrm{O}_{3}$ (for the oxide substrates) were calculated using equation (5).

Because the difference of $k_{1 \text {,obs }}$ (under a few ppb of $\mathrm{O}_{3}$ ) between $\mathrm{SiO}_{2}-1$ and $\mathrm{SiO}_{2}-2$ was within the uncertainty, their average value was used to calculate the lifetime of anthracene on $\mathrm{SiO}_{2}$. The lifetime of anthracene when reacting with $\mathrm{O}_{3}$ on $\mathrm{SiO}_{2}, \alpha-\mathrm{Al}_{2} \mathrm{O}_{3}$, and $\alpha-\mathrm{Fe}_{2} \mathrm{O}_{3}$ were calculated to be $4.66 \mathrm{~min}, 8.3 \mathrm{~min}$ and $18.2 \mathrm{~min}$, respectively, in highly polluted areas $\left(\left[\mathrm{O}_{3}\right]=500 \mathrm{ppb}\right.$ (Perraudin et al., 2007a)); and to be $1.51 \mathrm{~h}, 2.7 \mathrm{~h}$ and $5.96 \mathrm{~h}$ in clean areas $\left(\left[\mathrm{O}_{3}\right]=25 \mathrm{ppb}\right)$, respectively. Taking into account the results from previous studies (Table 2), the lifetime of anthracene ranged from 3 min on phenylsiloxane oil to approximately $51 \mathrm{~h}$ on hexanoic acid surfaces in highly polluted areas and from $0.48 \mathrm{~h}$ to approximately 42 days in clean areas, respectively. Considering that mineral dust is the largest contributor to particulate matter in the atmosphere, and that the reaction of $\mathrm{O}_{3}$ with anthracene adsorbed on mineral dust was faster than that on organic particle surfaces, it highlights the importance of the nature of the support and suggests that these reactions are an important sink of PAHs in highly polluted regions.

\section{Conclusions}

In order to improve our understanding of how the aerosol substrate influences the heterogeneous reaction of ozone with anthracene, we systemically investigated the kinetic of the heterogeneous reaction of ozone with anthracene adsorbed on different mineral oxides $\left(\mathrm{SiO}_{2}, \alpha-\mathrm{Al}_{2} \mathrm{O}_{3}\right.$ and $\left.\alpha-\mathrm{Fe}_{2} \mathrm{O}_{3}\right)$. This work showed that the reactions between ozone and anthracene adsorbed on mineral oxides proceed by the Langmuir-Hinshelwood mechanism.

The lifetime of anthracene on $\mathrm{SiO}_{2}, \alpha-\mathrm{Al}_{2} \mathrm{O}_{3}$, and $\alpha-\mathrm{Fe}_{2} \mathrm{O}_{3}$ due to reaction with $\mathrm{O}_{3}$ were calculated to be $4.66 \mathrm{~min}, 8.3 \mathrm{~min}$ and $18.2 \mathrm{~min}$, respectively, in highly polluted areas $\left(\left[\mathrm{O}_{3}\right]=500 \mathrm{ppb}\right)$; and to be $1.51 \mathrm{~h}, 2.7 \mathrm{~h}$ and $5.96 \mathrm{~h}$ in clean areas $\left(\left[\mathrm{O}_{3}\right]=25 \mathrm{ppb}\right)$, respectively. Compared to that on carbonaceous aerosols, the shorter lifetimes on mineral oxides suggest that these reactions may be an important sink for PAHs in highly polluted areas. Thus, mineral dust needs to be considered into accurate models for estimation the reactive fate of PAHs in the atmosphere.

Additionally, the difference among the rate constants and lifetimes of ozonization of anthracene on different oxides measured in this work showed that the nature of substrate has a strong influence on the heterogeneous reactions between ozone and anthracene. The oxide with higher decomposition rate constant of $\mathrm{O}_{3}$ (such as $\alpha-\mathrm{Fe}_{2} \mathrm{O}_{3}$ ) showed a lower reactivity of anthracene. Thus, the substrate effect of oxides on the reactions between ozone and anthracene can be ascribed to the difference in the decomposition reactivity of $\mathrm{O}_{3}$ on oxides. It should be pointed out that the nature mineral dust may have less catalytic effect to ozone decomposition, thus, the result must be carefully extrapolate to real atmosphere environment.

\section{Acknowledgements}

This research was funded by the Ministry of Science and Technology, China (2007CB407301), the National Natural Science Foundation of China (20937004, 50921064) and the Chinese Academy of Sciences (KZCX2-YW-Q02-03).

\section{References}

Alebić-Juretić, A., Cvitaš, T., Klasinc, L., 1990. Heterogeneous polycyclic aromatic hydrocarbons degradation with ozone on silica gel carrier. Environmental Science and Technology 24, 62-66.

Ammann, M., Pöschl, U., Rudich, Y., 2003. Effects of reversible adsorption and Langmuir-Hinshelwood surface reactions on gas uptake by atmospheric particles. Physical Chemistry Chemical Physics 5, 351-356.

Bedjanian, Y., Nguyen, M.L., 2010. Kinetics of the reactions of soot surface-bound polycyclic aromatic hydrocarbons with the $\mathrm{O}_{3}$. Chemosphere 79, 387-393.

Bedjanian, Y., Nguyen, M.L., Bras, G.L., 2010. Kinetics of the reactions of soot surfacebound polycyclic aromatic hydrocarbons with the $\mathrm{OH}$ radicals. Atmospheric Environment 44, 1754-1760.

Calvert, J.G., Atkinson, R., Becker, K.H., Kamens, R.M., Seinfeld, J.H., Wallington, T.J., Yarwood, G., 2002. The Mechanisms of Atmospheric Oxidation of Aromatic Hydrocarbons. Oxford University Press, Oxford.

Dentener, F.J., Carmichael, G.R., Zhang, Y., Lelieveld, J., Crutzen, P.J., 1996. Role of mineral aerosol as a reactive surface in the global troposphere. Journal of Geophysical Research 101, 22869-22889.

Finlayson-Pitts, B.J., Pitts Jr., J.N., 1997. Tropospheric air pollution: ozone, airborne toxics, polycyclic aromatic hydrocarbons, and particles. Science 276, 1045-1052.

Fu, S., Li, K., Xia, X.J., Xu, X.B., 2009. Polycyclic aromatic hydrocarbons residues in sandstorm depositions in Beijing, China. Bulletin of Environmental Contamination and Toxicology 82, 162-166.

Gloaguen, E., Mysak, E.R., Leone, S.R., Ahmed, M., Wilson, K.R., 2006. Investigating the chemical composition of mixed organic-inorganic particles by "soft" vacuum ultraviolet photoionization: the reaction of ozone with anthracene on sodium chloride particles. International Journal of Mass Spectrometry 258, 74-85.

Goriaux, M., Jourdain, B., Temime, B., Besombes, J.L., Marchand, N., Albinet, A., LeozGarziandia, E., Wortham, H., 2006. Field comparison of PAH measurements using a low flow denuder device and conventional sampling systems. Environmental Science and Technology 40, 6398-6404.

He, H., Liu, J.F., Mu, Y.J., Yu, Y.B., Chen, M.X., 2005. Heterogeneous oxidation of carbonyl sulfide on atmospheric particles and alumina. Environmental Science and Technology 39, 9637-9642.

Kahan, T.F., Kwamena, N.O.A., Donaldson, D.J., 2006. Heterogeneous ozonation kinetics of polycyclic aromatic hydrocarbons on organic films. Atmospheric Environment 40, 3448-3459.

Karcher, W., Fordham, R.J., 1987. Spectral Atlas of Polycyclic Aromatic Compounds. Kluwer Academic Publishers, Boston.

Kwamena, N.O.A., Thornton, J.A., Abbatt, J.P.D., 2004. Kinetics of surface-bound benzo[a]pyrene and ozone on solid organic and salt aerosols. Journal of Physical Chemistry A 108, 11626-11634. 
Kwamena, N.O.A., Earp, M.E., Young, C.J., Abbatt, J.P.D., 2006. Kinetic and product yield study of the heterogeneous gas-surface reaction of anthracene and ozone. Journal of Physical Chemistry A 110, 3638-3646.

Kwamena, N.O.A., Clarke, J.P., Kahan, T.F., Diamond, M.L., Donaldson, D.J., 2007a. Assessing the importance of heterogeneous reactions of polycyclic aromatic hydrocarbons in the urban atmosphere using the Multimedia Urban Model. Atmospheric Environment 41, 37-50.

Kwamena, N.O.A., Staikova, M.G., Donaldson, D.J., George, I.J., Abbatt, J.P.D., 2007b. Role of the aerosol substrate in the heterogeneous ozonation reactions of surface-bound PAHs. Journal of Physical Chemistry A 111, 11050-11058.

Li, W., Oyama, S.T., 1998. Mechanism of ozone decomposition on a manganese oxide catalyst. 2. Steady-state and transient kinetic studies. Journal of the American Chemical Society 120, 9047-9052.

Li, W., Gibbs, G.V., Oyama, S.T., 1998. Mechanism of ozone decomposition on a manganese oxide catalyst. 1. In situ Raman spectroscopy and ab initio molecular orbital calculations. Journal of the American Chemical Society 120, 9041-9046.

Michel, A.E., Usher, C.R., Grassian, V.H., 2003. Reactive uptake of ozone on mineral oxides and mineral dusts. Atmospheric Environment 37, 3201-3211.

Miet, K., Le Menach, K., Flaud, P.M., Budzinski, H., Villenave, E., 2009. Heterogeneous reactions of ozone with pyrene, 1-hydroxypyrene and 1-nitropyrene adsorbed on particles. Atmospheric Environment 43, 3699-3707.

Mmereki, B.T., Donaldson, D.J., 2003. Direct observation of the kinetics of an atmospherically important reaction at the air-aqueous interface. Journal of Physical Chemistry A 107, 11038-11042.

Mmereki, B.T., Donaldson, D.J., Gilman, J.B., Eliason, T.L., Vaida, V., 2004. Kinetics and products of the reaction of gas-phase ozone with anthracene adsorbed at the air-aqueous interface. Atmospheric Environment 38, 6091-6103.

Oyama, S.T., 2000. Chemical and catalytic properties of ozone. Catalysis ReviewsScience and Engineering 42, 279-322.

Perraudin, E., Budzinski, H., Villenave, E., 2007a. Kinetic study of the reactions of ozone with polycyclic aromatic hydrocarbons adsorbed on atmospheric model particles. Journal of Atmospheric Chemistry 56, 57-82.

Perraudin, E., Budzinski, H., Villenave, E., 2007b. Identification and quantification of ozonation products of anthracene and phenanthrene adsorbed on silica particles. Atmospheric Environment 41, 6005-6017.
Pflieger, M., Goriaux, M., Temime-Roussel, B., Gligorovski, S., Monod, A., Wortham, H., 2009. Validation of an experimental setup to study atmospheric heterogeneous ozonolysis of semi-volatile organic compounds. Atmospheric Chemistry and Physics 9, 2215-2225.

Pierce, R.C., Katz, M., 1975. Dependency of polynuclear aromatic hydrocarbon content on size distribution of atmospheric aerosols. Environmental Science and Technology 9, 347-353.

Pitts Jr., J.N., Van Cauwenberghe, K.A., Grosjean, D., Schmid, J.P., Fitz, D.R., Belser Jr., W.L., Knudson, G.B., Hynds, P.M., 1978. Atmospheric reactions of polycyclic aromatic hydrocarbons: facile formation of mutagenic nitro derivatives. Science 202, 515-519.

Pöschl, U., Letzel, T., Schauer, C., Niessner, R., 2001. Interaction of ozone and water vapor with spark discharge soot aerosol particles coated with benzo[a]pyrene: $\mathrm{O}_{3}$ and $\mathrm{H}_{2} \mathrm{O}$ adsorption, benzo[a]pyrene degradation, and atmospheric implications. Journal of Physical Chemistry A 105, 4029-4041.

Pöschl, U., Rudich, Y, Ammann, M. 2007. Kinetic model framework for aerosol and cloud surface chemistry and gas-particle interactions - part 1: general equations, parameters, and terminology. Atmospheric Chemistry and Physics 7, 5989-6023.

Ravishankara, A.R., 1997. Heterogeneous and multiphase chemistry in the troposphere. Science 276, 1058-1065.

Schauer, C., Niessner, R., Pöschl, U., 2003. Polycyclic aromatic hydrocarbons in urban air particulate matter: decadal and seasonal trends, chemical degradation, and sampling artifacts. Environmental Science and Technology 37, 2861-2868.

Shiraiwa, M., Garland, R.M., Pöschl, U., 2009. Kinetic double-layer model of aerosol surface chemistry and gas-particle interactions (K2-SURF): degradation of polycyclic aromatic hydrocarbons exposed to $\mathrm{O}_{3}, \mathrm{NO}_{2}, \mathrm{H}_{2} \mathrm{O}, \mathrm{OH}$ and $\mathrm{NO}_{3}$. Atmospheric Chemistry and Physics 9, 9571-9586.

Usher, C.R., Michel, A.E., Grassian, V.H., 2003. Reactions on mineral dust. Chemical Reviews 103, 4883-4939.

Wu, C.H., Salmeen, I., Niki, H., 1984. Fluorescence spectroscopic study of reactions between gaseous ozone and surface-adsorbed polycyclic aromatic hydrocarbons. Environmental Science and Technology 18, 603-607.

Wu, S.P., Tao, S., Xu, F.L., Dawson, R., Lan, T., Li, B.G., Cao, J., 2005. Polycyclic aromatic hydrocarbons in dustfall in Tianjin, China. Science of the Total Environment 345, 115-126. 